\title{
Age revision of Carboniferous rocks in the northern part of the Intra-Sudetic Basin (SW Poland) based on miospore data
}

\author{
Anna GÓRECKA-NOWAK ${ }^{1, *}$, Adrianna JANKOWSKA ${ }^{1}$ and Jolanta MUSZER ${ }^{1}$ \\ 1 University of Wrocław, Institute of Geological Sciences, Cybulskiego 30, 50-205 Wrocław, Poland
}

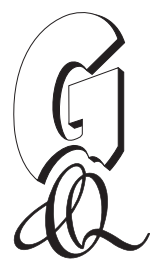

Górecka-Nowak, A., Jankowska, A., Muszer, J., 2021. Age revision of Carboniferous rocks in the northern part of the Intra-Sudetic Basin (SW Poland) based on miospore data. Geological Quarterly, 2021, 65: 8, doi: 10.7306/gq.1581

Associate Editor: Michał Zatoń

Palynostratigraphic studies of the Carboniferous strata of the Szczawno and Wałbrzych formations, outcropping in the vicinity of Wałbrzych in the northern part of the Intra-Sudetic Basin, are reported. Rocks of the Szczawno Formation in a section near Konradów had earlier been assigned to the Upper Visean, while rocks of the Wałbrzych Formation in the Biały Kamien section were included to the Lower Namurian [the Stenozonotriletes triangulus-Rotaspora knoxi (TK) Miospore Zone]. This study describes abundant palynological material with many taxonomically diverse miospore assemblages from these rocks, allowing precise palynostratigraphic conclusions. These showed that the rocks of the Szczawno Formation studied should be referred to the lower part of the Serpukhovian [Verrucosisporites morulatus $(\mathrm{Vm})$ Subzone], correlated with the lowest Namurian, while rocks of the Wałbrzych Formation from Biały Kamień belong to the Lower Bashkirian [Lycospora subtriquetra-Cirratriradites rarus (SR) Subzone], correlated with the Upper Namurian A. These results indicate that the rocks from both sections studied are younger than they were earlier believed. This revises the age of the Szczawno and Wałbrzych formations in the northern part of the Intra-Sudetic Basin which belong to four miospore zones, from Vm to SR, corresponding to the Serpukhovian and lowermost Bashkirian (Namurian A corresponding to the Pendleian to Alportian of British chronostratigraphy).

Key words: miospores, palynostratigraphy, age revision, Serpukhovian, Bashkirian, Namurian, Intra-Sudetic Basin.

\section{INTRODUCTION}

The study area is located in the northern part of the IntraSudetic Basin, called also the Intra-Sudetic Synclinorium (Żelaźniewicz et al., 2011), which is a large Variscan intramontane basin located in the Central Sudetes (Fig. 1A). It is infilled with Carboniferous-Permian volcano-sedimentary rocks, which are overlain by Lower Triassic and Upper Cretaceous strata (e.g., Awdankiewicz et al., 2003). The geological evidence of the Carboniferous age of rocks is good and the fossiliferous marine strata of the Szczawno Formation and the coal-bearing Wałbrzych Formation are widely recognized lithostratigraphical units in this basin.

Geological studies of the Intra-Sudetic Basin started at the beginning of the 19th century. The first exploratory works were conducted by von Buch (1802) and Raumer (1819). This great geological reconnaissance of the Carboniferous rocks was as-

\footnotetext{
* Corresponding author, e-mail: anna.gorecka-nowak@uwr.edu.pl Received: August 31, 2020; accepted: November 24, 2020; first published online: March 10, 2021
}

sociated with exploitation of bituminous coal in mines of the Lower Silesian Coal Basin. At the beginning of the 20th century some geological maps of this region were published and explanations to part of them contained precise descriptions of Carboniferous rocks and their division into lithostratigraphic units (Berg, 1921; Dathe and Finckh, 1924). Many geological studies on the Szczawno and Wałbrzych formations were published after World War II. The earliest of these were by Radwański (1952), Teisseyre $(1952,1958)$ and Żak (1958). Subsequently, the studies of Dziedzic (1960, 1968, 1971), Grocholski (1960, 1963, 1974), Grocholski and Augustyniak (1971), Teisseyre (1968, 1975), Nemec et al. (1982), Nemec (1984), Mastalerz and Porębski (1987), Mastalerz (1987, 1995), Dziedzic and Teisseyre (1990), Bossowski et al. (1995) and Mastalerz and Prouza (1995) allowed better geological recognition of these units, including inferences of sedimentary environment. Coal seams in the Wałbrzych Formation have also been studied petrologically (Mastalerz, 1992; Nowak, 2000; Uglik and Nowak, 2015). The Wałbrzych area remains of geological interest and our present studies show that useful new information may be obtained, to change the interpretation of various aspects of the rocks studied.

This paper describes palynostratigraphic data from the Szczawno and Wałbrzych formations, this method affording an accurate dating of Carboniferous rocks of both continental and marine origin. Miospores are common in these rocks and de- 


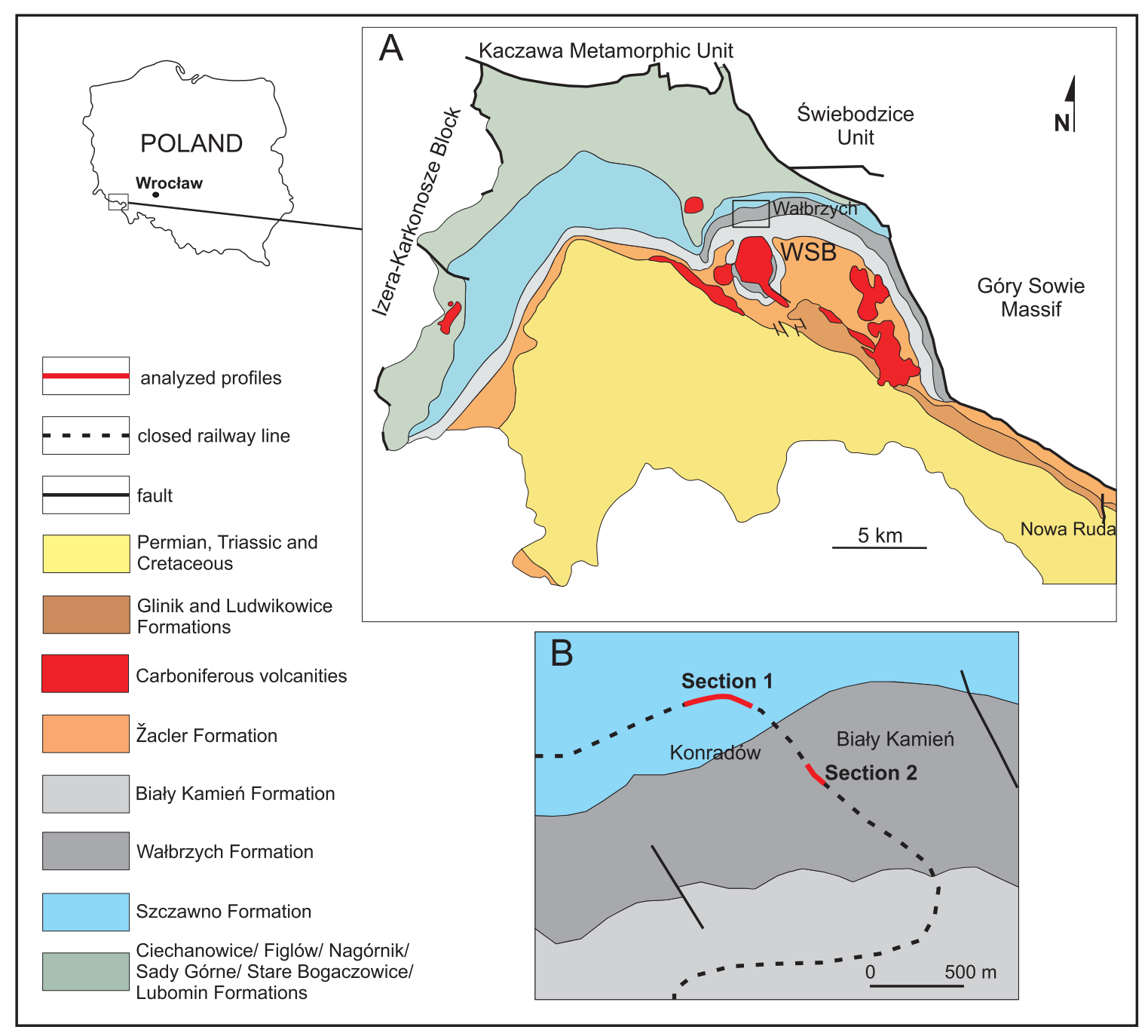

Fig. 1A - geological map of the Intra-Sudetic Basin (based on Sawicki, 1966, modified) with location of the study area marked (WSB - Wałbrzych Sub-Basin); B - geological sketch of study area (based on Sawicki, 1995, modified) showing location of the profiles studied

tailed miospore zonations of the Carboniferous are available (Clayton et al., 1977; Owens et al., 2004). In this study, new miospore data has allowed revision of the age of the rocks studied.

Previous dating of the Szczawno Formation as Upper Visean has been based on marine macrofossils (Żakowa, 1958, 1960a, b, 1963). Palynostratigraphic analysis of these rocks has only recently been made. Abundant and taxonomically diverse miospore assemblages, showing that the rocks studied are younger than previously believed. These new results from the Konradów section (Fig. 1B) were noted by Muszer et al. (2016a) and in this paper they are described in detail. For the Wałbrzych Formation, new palynostratigraphic studies are limited to these parts of the Biały Kamien section (Fig. 1B) not previously studied by Górecka-Nowak and Majewska (2002, 2003). The miospore assemblages determined here have allowed slight adjustment of the earlier stratigraphical conclusions.

\section{GEOLOGICAL SETTING}

The Carboniferous sedimentary rocks of the Intra-Sudetic Basin are mainly clastic and $\sim 8.5 \mathrm{~km}$ thick (Nemec et al., 1982; Dziedzic and Teisseyre, 1990). The onset of sedimentation in this intramontane basin was in the Mississippian, not earlier than in the Middle Visean (Turnau et al., 2002). Sedimentation continued until the end of the Carboniferous and into the Permian. The succession, divided into several informal lithostratigraphical units (formations, formerly called "beds" (e.g., Nemec et al., 1982; Bossowski et al., 1995; Fig. 2) is the most complete record of geological events during the Carboniferous in the Sudetes.

The study area is located in the northern part of the Intra-Sudetic Basin, termed the Wałbrzych Sub-Basin (WSB; Fig. 1A). This is small basin $\sim 12 \mathrm{~km}$ long and $8 \mathrm{~km}$ wide and, except for its SW boundary, is fault-bounded. The Wałbrzych 


\begin{tabular}{|c|c|c|c|}
\hline \multicolumn{2}{|c|}{ Lithostratigraphy } & $\begin{array}{c}\text { Thickness } \\
{[\mathrm{m}]}\end{array}$ & \\
\hline \multicolumn{2}{|c|}{ Ludwikowice Fm. } & $100-440$ & \\
\hline \multicolumn{2}{|c|}{ Glinik Fm. } & $300-850$ & \\
\hline \multicolumn{2}{|c|}{ Žacler Fm. } & $500-900$ & \\
\hline \multicolumn{2}{|c|}{ Biały Kamień Fm. } & $150-380$ & \\
\hline \multicolumn{2}{|c|}{ Wałbrzych Fm. } & $250-300$ & $\begin{array}{c}\text { section } 2 \\
\text { (Biały Kamień) }\end{array}$ \\
\hline \multicolumn{2}{|c|}{ Szczawno Fm. } & $600-3000$ & $-\begin{array}{c}\text { section } 1 \\
\text { (Konradów) }\end{array}$ \\
\hline \multicolumn{2}{|c|}{ Lubomin Fm. } & $1500-2100$ & \\
\hline \multicolumn{2}{|c|}{ Stare Bogaczowice Fm. } & $1000-1800$ & \\
\hline $\begin{array}{c}\text { Ciechanowice } \\
\text { Fm. }\end{array}$ & \begin{tabular}{|c|c|c|} 
Nagórnik & Sady & Figlów \\
Fm. & Gorne & Fm. \\
\end{tabular} & $0-1000$ & \\
\hline
\end{tabular}

Fig. 2. Lithostratigraphy of the Carboniferous in the Intra-Sudetic Basin (based on Bossowski et al., 1995)

Grey colour marks studied formations

Sub-Basin is infilled with Carboniferous sedimentary rocks, their outcrop forming an arch open to the south. Volcanic rocks occur among the sedimentary rocks, mainly in the marginal part of this sub-basin (Awdankiewicz et al., 2003). The sedimentary strata dip towards the centre of the WSB and are tectonically disturbed in the vicinity of volcanic bodies.

Three formations occur in the study area in the vicinity of Wałbrzych: Szczawno Formation, Wałbrzych Formation and Biały Kamień Formation (Fig. 1B). Their strata are mostly of continental origin, except for the Szczawno Formation, which consists of fluvial-deltaic and marine deposits (Mastalerz and Prouza, 1995; Bossowski et al., 1995).

The Szczawno Formation (formerly named the "Upper Culm" or "Younger Culm" - see Radwański, 1952) outcrop forms a belt in the northern part of the Intra-Sudetic Basin (Fig. 1A). Its thickness varies from 400 to $600 \mathrm{~m}$ in the eastern part of the basin to $\sim 3000 \mathrm{~m}$ in its western part (Nemec et al., 1982; Bossowski et al.,1995). This formation consists of sandstones and mudstones intercalated with conglomerates. Within it, Mastalerz (1995) distinguished six facies: alluvial-delta plain, fan-delta front, prodelta, subaqueous fan, basin plain and slope, and shallow-marine shelf. In the Wałbrzych Sub-Basin (WSB) the Szczawno Formation passes upwards into non-marine strata of the Wałbrzych Formation (e.g., Grocholski, 1960; Teisseyre, 1961; Nemec et al., 1982), which is the older coal-bearing unit of this region. In the eastern part of the WSB the contact between these two lithostratigraphic units is partly tectonic (Berg, 1925; Nemec, 1984). In the western part of the Intra-Sudetic Basin, the Szczawno Formation is unconformably overlain by Westphalian deposits (Nemec et al., 1982).

There have been several studies of the contact between the Szczawno and Wałbrzych formations, which was once considered as the Lower/Upper Carboniferous boundary (e.g., Teisseyre, 1961; Dziedzic, 1960, 1968, 1971; Grocholski and Augustyniak, 1971; Nemec, 1984; Bossowski et al., 1995; Mastalerz, 1995; Mastalerz and Prouza, 1995). This contact is still not fully resolved. German geologists (e.g., Dathe, 1891; Dathe and Petrascheck, 1913; Berg, 1925, 1938; Bederke, 1929) inferred an unconformity between the Upper Culm (Upper Visean) and the Wałbrzych beds (Lower Namurian) or the Lower and Upper Carboniferous. However, Teisseyre (1961) described "passage beds" without marine fauna between the Culm of Szczawno and the Wałbrzych beds on the northern margin of the Wałbrzych Coal Basin. He stated, that "there is no sharp boundary between both sequences". According to Dziedzic (1971) at the passage from the Szczawno Formation into the Wałbrzych Formation in the Wałbrzych region "...no essential differences have been observed concerning either the outward appearance of sediments and their arrangement pattern of symptoms suggesting changes in the conditions of deposition...". Dziedzic (1971) stated also that the situation is different in the Nowa Ruda region, where an unconformity between the Lower and the Upper Carboniferous is clear and according to Dathe $(1901,1904)$, Bederke (1929) and Oberc (1957) indicates the influence of the Sudetic phase. Tectonic uplift of the eastern and southern Intra-Sudetic Basin borders around the Visean/Namurian boundary led to rearrangement of the basin and its depositional systems (Mastalerz, 1987; Mastalerz and Prouza, 1995; Awdankiewicz et al., 2003). These authors suggested that marine regression occurred in the latest Visean, and the succeeding Upper Carboniferous succession accumulated in continental environments from the Namurian onwards. There has also been wide recognition that the siliciclastic deposits of the Szczawno Formation are compositionally of low maturity, in contrast to the more mature clastic material of the Wałbrzych Formation. The boundary between these formations is marked by the disappearance of greywackes and the appearance of quartz conglomerates or of a significant number of coal layers and seams (Nemec et al., 1982).

The Wałbrzych Formation consists mainly of sandstones with variable large and small scale stratification, with conglomerates, mudstones and claystones and numerous plant fossils. This formation is coal-bearing, with 30 coal seams exploited in the past in mines of the Lower Silesian Coal Basin. The thickness of this formation reaches up to 300 metres in the WSB. These rocks were described in detail in terms of sedimentology by Nemec (1984), who distinguished seven lithofacies in them. The lithological diversity of the rocks in the Wałbrzych Formation is a result of varied conditions within the alluvial environment where sedimentation took place. The presence of sandstones and conglomerates usually indicates fluvial channel sedimentation. The coal seams indicate long-term phytogenic accumulation in the flood basin. In turn, mudstones indicate the deposition of suspended matter in standing water, in extrachannel zones in the flood basin (Nemec, 1984).

Conglomerates and sandstones of the Biały Kamien Formation occur above the Wałbrzych Formation in the WSB. This lithostratigraphic unit consists mainly of coarse conglomerates and sandstones, while in its upper part mudstones and thin coal seams also appear. Above the Biały Kamień Formation, though out of the studied area (and not shown in Fig. 1B) is the coal-bearing Żacler Formation. The Biały Kamień and Żacler formations occupy the central part of the WSB (Fig. 1A).

The study area is located in the vicinity of Wałbrzych, between Konradów and Biały Kamień, exposures being connected to the old railway line (Fig. 1B). The Szczawno Formation outcrops close to Konradów and this part includes section 1 of this study, which is one of the best exposures of this formation in the Intra-Sudetic Basin (Fig. 3). There are exposures of the Wałbrzych Formation in the vicinity of the old Biały Kamien railway station, called here section 2 (Fig. 4).

Section 1 near Konradów is $\sim 400 \mathrm{~m}$ long and is located along the railway cutting. The Szczawno Formation in this section (Fig. 3) may be divided into three parts. The lower part is dominated by fine-grained clastic rocks - dark grey and greenish grey mudstones with rare intercalations of limestone and a 


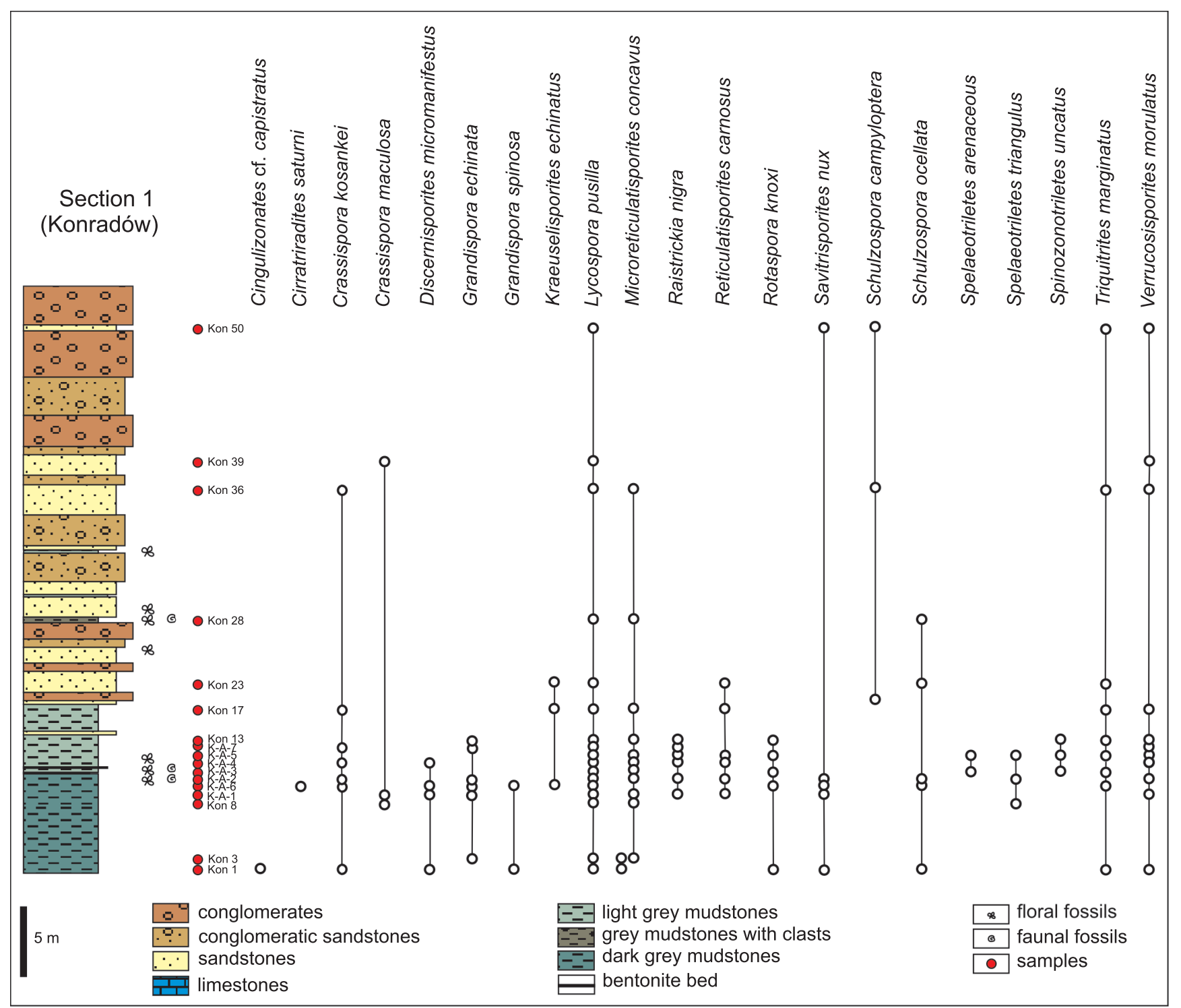

Fig. 3. Lithology of section 1 (Konradów profile, Szczawno Formation) with vertical distribution of some important miospore taxa found in the rocks studied

bentonite bed. Rare faunal macrofossils occur in these rocks. The middle part of the Konradów section has a transitional character. It is dominated by sandstones with intercalations of grey mudstone, conglomeratic sandstone and conglomerate. In this part, rare fossils, mainly of plants, occur. The upper part of the profile is dominated by conglomerates and conglomeratic sandstones with intercalations of sandstone.

Walking along the old railway line towards the disused station Biały Kamień there is an exposure gap of $\sim 500 \mathrm{~m}$. It likely conceals the boundary between the Szczawno and Wałbrzych formations beneath Quaternary deposits.

Rocks of the Wałbrzych Formation were studied and sampled in section 2 (Fig. 1B), which consists of several isolated exposures, marked A-F (Fig. 4). Sandstones predominate in the lower and middle parts of this 150 metre-long section and only in its uppermost part are mudstones more common. The lower and middle parts of the profile are represented by light grey sandstones, ranging from very fine to coarse-grained. Additionally, in the lower part of the profile, specifically in the uppermost part of exposure $B$, one thin coal bed occurs (up to $20 \mathrm{~cm}$ thick).
The upper part of the profile is dominated by brown-grey mudstones. The coal seam, correlated with the seam number 678 , occurs in this part of section 2.

\section{PREVIOUS BIOSTRATIGRAPHICAL RESULTS}

Palaeontological and biostratigraphical studies of the Carboniferous rocks in the Intra-Sudetic Basin began from nineteenth-century studies of macrofauna at individual sites within the Szczawno Formation of the Wałbrzych vicinity (see Żakowa, 1958 and references therein), with subsequent monographs describing these marine fossils (gastropods, brachiopods, goniatites) (Kühne, 1930; Paeckelmann, 1930, 1931; Schmidt, 1930; Nekhoroshev, 1932).

The first regional stratigraphic division of the Carboniferous based on macroflora was proposed by Gothan and Gropp (1933), with a later stratigraphic synthesis by Bederke and Fricke (1943). After World War II, further stratigraphic studies 


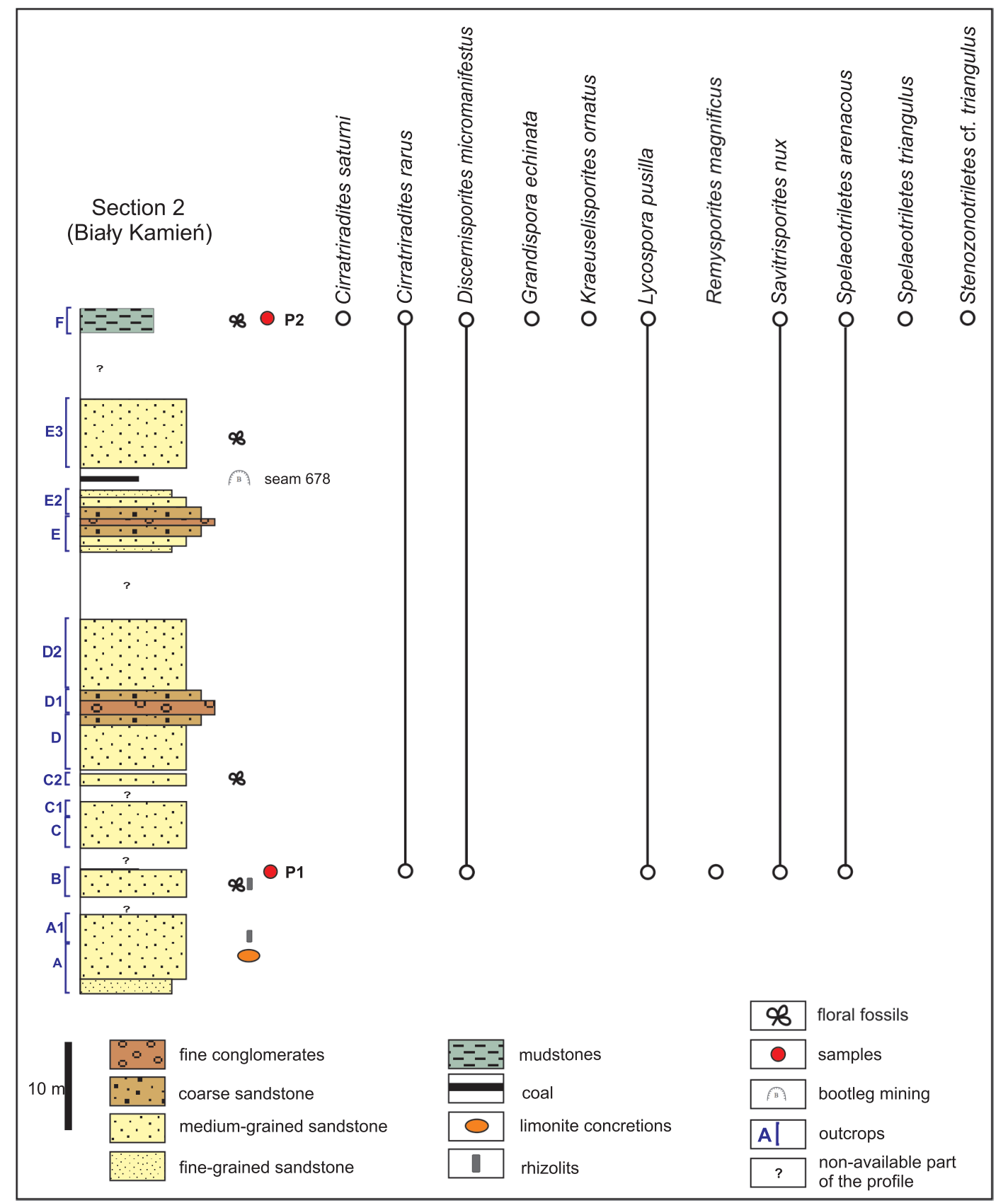

Fig. 4. Lithology of section 2 (Biały Kamień profile, Wałbrzych Formation) with vertical distribution of some important miospore taxa found in the rocks studied

were carried out. Plant fossils were studied by Zimmerman (1956), while Żakowa (1958, 1960a, b, 1963) and Jerzykiewicz (1965) continued studies of the Szczawno Formation rocks, based on macrofaunal fossils.

New stratigraphic data on the Carboniferous rocks in the Intra-Sudetic Basin were obtained in the 1960s, when palynological studies began, allowing more precise dating and refinements of their stratigraphic interpretation. Górecka (1962) studied the coal-bearing Wałbrzych Formation in the Wałbrzych Sub-Basin (WSB) while Krawczyńska-Grocholska (1966) studied rocks of the same formation from the Nowa Ruda Sub-Basins (NRSB). Later Górecka-Nowak and Majewska (2002, 2003) made further studies of this formation in the WSB, applying the miospore zonation of Clayton et al. (1977). The Biały Kamień Formation from the NW part of the Intra-Sudetic Basin was palynologically studied by Górecka $(1968,1969)$, and Górecka-Nowak $(1987,1988,1995)$ studied the Westphalian deposits focusing on the Żacler Formation. Rocks of the uppermost Carboniferous and lowermost Permian were palynologically studied by Górecka (1981) and Jerzykiewicz (1987). Their stratigraphic interpretations differ and the C/P boundary in the Sudetes remains unresolved.

Palynological analysis of the Carboniferous of the IntraSudetic Basin did not encompass Mississippian rocks, with the exception of the oldest levels, previously interpreted as Tournaisian (Teisseyre, 1968, 1975; Mastalerz and Prouza, 1995). 
The palynological studies of Turnau et al. (2002) showed that the onset of sedimentation in the Intra-Sudetic Basin was not earlier than the Middle Visean.

This paper provides new palynostratigraphical data from the Szczawno and Wałbrzych formations. The palaeontological documentation of the Szczawno Formation is extensive (e.g., goniatites, bivalves, brachiopods, trilobites) and records a marine transgression. According to Żakowa (1958, 1960a, b, 1963) it contains goniatites, which are index taxa to the crenistria (Goo) (Prolecanites serpentinus, Beyrichioceras truncatum and Goniatites crenistria) and striatus (Go $\beta$ ) zones (Goniatites striatus spirifer, Goniatites striatus striatus and Goniatites striatus falcatus). These results suggest assignment to the Upper Visean.

Microfaunal studies of the Szczawno Formation have been carried out at only one site, Ptasia Góra near Wałbrzych (Woszczyńska, 1967). The foraminifers recovered are geographically widespread taxa, some considered to be characteristic of the Lower Carboniferous (Pseudoendothyra struvei, Ammodiscus volgensis, Valvulinella youngi, Plectogyra excentralis). One taxon is known from the Upper Mississippian (Plectogyra excentralis) and some species (Endothyranopsis crassus, Stacheia pupoides, Tetrataxis conica) range into the Pennsylvanian (see Woszczyńska, 1967).

The presence of the Upper Visean fossils in marine deposits near Konradów (section 1 in this paper) were previously reported by German geologists (e.g., Dathe, 1892a, b; Dathe and Berg, 1926; Paeckelmann, 1930, 1931). They listed some bivalves, trilobites, brachiopods and plants (see Żakowa, 1960a): e.g. Aviculopecten nobilis de Kon., Aviculopecten orbiculatus McCoy, Phillipsia sp., Gigatoproductus gigantoides (Paeckelm.), G. latissimus (Sow.), Chonetipustula carringtoniana (Davidson), Asterocalamites (presently Archaeocalamites) radiatus, Cardiopteris frondosa. Żakowa (1960a) on the basis of these and Zimmermann's collections listed additional Upper Visean taxa: e.g. Goniatites striatus striatus (Sow.), Goniatites striatus falcatus Roem., Nomismoceras germanicum Schmidt, Posidonia becheri Bronn., Plicochonetes waldschmidti (Paeckelm.), Eomarginifera simplex (Paeckelm.) and Dictyoclostus zimmermanni (Paeckelm.), and assigned the strata at Konradów to the Goniatites striatus striatus $\left(\mathrm{Go} \beta_{2}\right)$ and Goniatites striatus falcatus $\left(\mathrm{Go} \beta_{3}\right)$ zones. Additionally, Jerzykiewicz (1965) gave brief description of other Lower Carboniferous fossils (brachiopods, gastropods and bivalves) from this locality: e.g. Rhipidomella michelini (Léveillé), Schuchertella portlockiana (v. Sem.), Platyschizma glabrata Phill., Parallelodon lacordaireanus (de Kon.). Osmólska (1968) also described the trilobite Archeogonus (Phillibole) aprathensis richteri from Konradów and assigned this taxon to the Upper Visean on the basis of the biostratigraphic results of Żakowa (1960a).

Miospore assemblages of the Szczawno Formation, initially outlined by Muszer et al. (2016a), are described in detail in this paper. Palynostratigraphic results suggest that the rocks studied of the Szczawno Formation are younger than earlier thought.

Rocks of the Wałbrzych Formation were originally included to the Namurian A on the basis of paleaobotanical studies (Gothan, 1932; Zimmermann, 1956), with 50 species being recognized, including many species characteristic of the Namurian A such as Lyginopteris stangeri Štur, Lyginopteris larischi Štur and Diplotemema adiantoides (Schlotheim) Gothan. However, rocks of the Wałbrzych Formation in the WSB did not yield macroflora from the Upper Namurian A, which was found only in rocks of this formation in the Nowa Ruda area (Kotasowa and Migier, 1995). This suggests that the strata in the Nowa Ruda Sub-Basin (NRSB) are slightly youn- ger than in the WSB, although data from both basins indicate the Namurian A.

Palynological studies of the Wałbrzych Formation were initially applied only to rocks from the NRSB and their age was defined as Late Namurian A (Krawczyńska-Grocholska, 1966), a general assessment made before the miospore zonation of the Carboniferous was established. In the Wałbrzych area, rocks of this formation were systematically palynologically studied many years later. Two Early Namurian miospore zones of the zonation of Clayton et al. (1977), were distinguished: Stenozonotriletes triangulus-Rotaspora knoxi (TK) and Lycospora subtriquetra-Kraeuselisporites (SO) (Górecka-Nowak and Majewska, 2002, 2003). These biozones correspond to the middle and upper parts of the Namurian A, correlated with the Arnsbergian, Chokerian and lower part of the Alportian of British chronostratigraphy (Owens et al., 2004). Rocks from near the old railway station at Biały Kamień (section 2 here) were than included to the first of these zones, though the present palynostratigraphic results suggest a slight age revision, as discussed below.

\section{MATERIALS AND METHODS}

The biostratigraphical studies were made to place age constraints on the Szczawno and Wałbrzych formations in the WSB (Fig. 1A). During the fieldwork some macrofossils were found.

Those from the Szczawno Formation near Konradów (section 1; Fig. 3) are poorly preserved and represent mainly goniatites, bivalves, brachiopods and trilobites; some are fragmentary, or in pebbles, and so probably reworked (Muszer et al., 2016b). Some plant fossils of the Calamitaceae-Archaeocalamites radiatus (Bron.) Stur and Calamites (Mesocalamites) cf. renieri Stockmans et Williere - were found (Fig. 5A, B). A. radiatus occurs in the Lower Carboniferous, while the stratigraphic range of Calamites (Mesocalamites) renieri is much shorter and includes the Namurian A (Serpukhovian) (Boureau, 1964). Trace fossil assemblages were also found in this section, and will be separately described.

Some macroplant fossils were also found in the Wałbrzych Formation at section 2 (exposures B, C2, E2, E3 and F; Fig. 4). Most are partly coalified, fragmentary impressions of indeterminable stalks, mostly from exposure $F$. Among them, stem fragments of Lepidodendron veltheimi Sternberg (Fig. 5C-D) and Stigmaria sp. (Fig. 5E) were determined. Additionally, the C2 exposure yielded another impression of Stigmaria sp. and poorly preserved Calamitaceae shoot fragment. These poorly preserved plant macrofossils have little stratigraphical importance. Stigmaria has a long stratigraphic range, including the Carboniferous and Permian (Kotasowa and Migier, 2001). Lepidodendron veltheimi has a range, including the Late Visean and Namurian A (Kotasowa and Migier, 2001).

Rhizoliths were found for the first time in the lower part of the section 2 (exposures A and B). They are $2-4 \mathrm{~cm}$ long and oriented perpendicular to the strata. They will be separately described, but their presence and presence of Stigmaria indicate the occurrence of fossil soils. Earlier, Nemec (1984) mentioned stigmaria horizons in the section Biały Kamień only in coaly shale (upper part of the section), which is now unavailable.

Seventeen palynological samples of grey mudstone and dark grey siltstone from the Szczawno Formation were taken from section 1 (Fig. 3). The Wałbrzych Formation of section 2, mainly sandstones, offer limited possibilities and only two samples were taken: sample P1 is from a $20 \mathrm{~cm}$-thick coal layer low in the profile (exposure B), while sample P2 was 

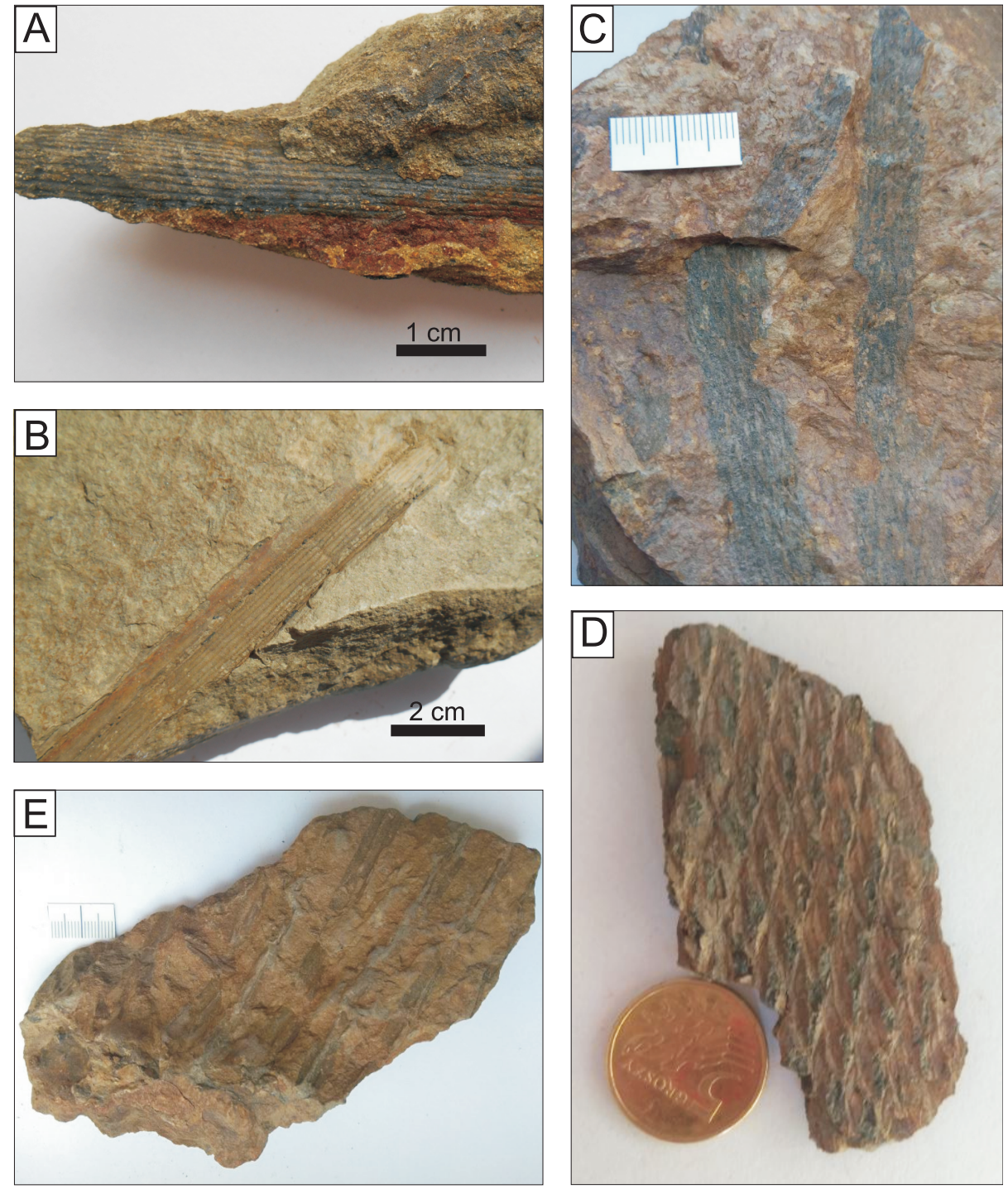

Fig. 5. Macrofloral fossils from the Konradów and Biały Kamień sections

A - Archaeocalamites radiatus (Bron.) Stur, section 1 (Konradów) (photo by Aleksandra Strzoda); B - Calamites (Mesocalamites) cf. renieri Stockmans et Williere, section 1 (Konradów) (photo by Aleksandra Strzoda); C - Lepidodendron veltheimi Sternberg, section 2 (Biały Kamień, exposure F-1) (photo by Adrianna Jankowska); D - Lepidodendron veltheimi Sternberg, exposure F-2) (photo by Adrianna Jankowska); E - Stigmaria sp., section 2 (Biały Kamień, exposure F-3) (photo by Adrianna Jankowska)

taken from mudstones of exposure $F$ in the highest part of this section (Fig. 4).

Rock samples were processed for the palynological studies in the standard way. After grinding, the mudstone samples were processed in hydrochloric acid and then with $40 \%$ hydrofluoric acid for $\sim 24$ hours. The next step was the oxidation of organic matter by Schulze's method using $65 \%$ nitric acid and potassium chlorate $\left(\mathrm{KClO}_{3}\right)$. A sample of bituminous coal was processed only by Schulze's method. After each processing step, all samples were carefully rinsed. Next, the residue was passed through a $16 \mu \mathrm{m}$ microsieve. Finally microscopic slides in gelatine-glycerin paste were made. A Nikon Optiphot microscope was used and microphotographs were taken using a Canon PowerShot $\mathrm{G}$ digital camera. Depending miospore frequency, two to six microscopic slides from each sample were studied.
All slides are stored in the Stratigraphy Department, Institute of Geological Sciences, University of Wrocław.

Abundant palynological material was found, including numerous miospores in all samples studied. The preservation of miospores from rocks of the Szczawno Formation is variable, but generally rather poor. Most miospores are mechanically damaged and some show traces of pyritization. Species determination was possible only for some specimens, as the preservation commonly allowed only generic determination. However, some moderately well-preserved miospores were found (Figs. 6 and 7). The miospores from the Wałbrzych Formation are better preserved although some are mechanically damaged, though without traces of pyritization. Miospore colour varies among the samples, from yellow to dark brown. Colours of miospores considered as reworked mostly do not differ from 
colours of the rest of miospores, though usually the darkest specimens are reworked. The miospore assemblages are taxonomically diverse with over 170 taxa belonging to 71 miospore genera (see Appendix*).

\section{STRATIGRAPHIC INTERPRETATION}

The miospore assemblages determined provide valuable data for stratigraphic interpretation (Figs. 3 and 4). They significantly include taxa that appeared in the Visean and occur also later in the Carboniferous, most importantly Lycospora, found in all samples studied, and Savitrisporites nux found in both the Szczawno and Wałbrzych formations. These common features of the miospore assemblages indicate that the rocks studied are not older than Visean. However, the miospore assemblages also contain other stratigraphically important components, as described below.

The miospore assemblage from the section 1 of the Szczawno Formation contains many taxa characteristic of the Late Visean and Serpukhovian (Early Namurian), such as Discernisporites micromanifestus, Grandispora echinata, Hymenospora palliolata, Knoxisporites triradiatus, Leiotriletes tumidus, Orbisporis orbiculus, Punctatisporites sinuatus and Waltzispora planiangulata. The relatively stable occurrence of Microreticulatisporites concavus, Raistrickia nigra, Reticulatisporites carnosus, Rotaspora knoxi and Schulzospora is stratigraphically important. The taxa Bellispores nitidus, Cingulizonates cf. capistratus, Kraeuselisporites echinatus, Spinozonotriletes uncatus and Triquitrites marginatus, also stratigraphically significant, were determined from some samples. Most importantly, two species, Crassispora kosankei and Verrucosisporites morulatus, both mark the beginning of the Namurian, and the lower boundary of the Serpukhovian (Fig. 8). This indi- cates that the rocks of the Szczawno Formation studied should be assigned to the Verrucosisporites morulatus (Vm) Subzone (Fig. 8), being the upper, Serpukhovian (Namurian), part of the Cingulizonates cf. capistratus-Reticulatisporites carnosus Miospore Zone (Owens et al., 2004). Verrucosisporites morulatus, which regularly occurs in rocks of the Szczawno Formation, has an unusually short stratigraphic range, limited to the $\mathrm{Vm}$ miospore subzone, which is correlated with the Lower Serpukhovian (Lower Namurian A in Central Europe and Pendleian on the British Isles).

In this Early Serpukhovian miospore assemblage, older miospores, which usually do not occur in rocks of this age, were also found. Auroraspora asperella and Auroraspora macra, Convolutispora vermiformis, Cyclogranisporites commodus, Murospora complicata, Potoniesporites delicatus, Punctatisporites irrasus, Rugospora minuta and the genera Gorgonispora, Labiadensites, Cribrosporites and Monilospora belong among them. All these miospores are considered as reworked.

The miospore assemblage determined from the Wałbrzych Formation of section 2 consists also of taxa characteristic of the Late Visean and Early Namurian but this association differs from that described above. It includes the taxa Leiotriletes tumidus, Cingulizonates bialatus and Cirratriradites saturni. Other stratigraphically important taxa, which Clayton et al. (1977) and Owens et al. (2004) used to establish a miospore zonation of the Visean and the Namurian, were also found, including Kraeuselisporites ornatus and Cirratriradites rarus, Stenozonotriletes cf. triangulus, Rotaspora knoxi and Tripartites vetustus (Fig. 6). It is not easy to interpret this miospore assemblage: the co-occurrence of these taxa is quite remarkable, as their stratigraphic ranges are different and usually they do not occur together. The presence of Rotaspora knoxi and Tripartites vetustus, which disappear at the top of the Mooreisporites trigallerus-Rotaspora knoxi (TK) Zone (Owens et al., 2004) seems to indicate that the rocks studied are not

\section{Fig. 6. Miospores from the Szczawno and Wałbrzych formations}

A - Punctatisporites sinuatus, Szczawno Formation, Konradów section, sample K-A 1, slide 2, F26/2-F27/1; B - Leiotriletes tumidus, Wałbrzych Formation, Biały Kamień section, sample P2, slide 5, U20/2; C - Leiotriletes tumidus, Wałbrzych Formation, Biały Kamień section, sample P1, slide 5, Z41/2; D - Waltzispora planiangulata, Szczawno Formation, Konradów section, sample K-A 6, slide 1, M 32; E Walzispora polita, Szczawno Formation, Konradów section, sample Kon 17, slide 1, R 26/2; F - Verrucosisporites morulatus, Szczawno Formation, Konradów section, sample K-A 5, slide 1, Z 31; G - Verrucosisporites morulatus, Szczawno Formation, Konradów section, sample K-A 5, slide 2, O32/4; H - Apiculatisporis irregularis, Szczawno Formation, Konradów section, sample K-A 6, slide 3, V42/3; I Raistrickia nigra, Szczawno Formation, Konradów section, sample K-A 5, slide 2, M 11/1; J - Microreticulatisporites concavus, Szczawno Formation, Konradów section, sample K-A 1, slide 1, T 9/2; K - Dictyotriletes vitilis, Wałbrzych Formation, Biały Kamień section, sample P2, slide 5, L60; L - Ahrensisporites guerickei, Szczawno Formation, Konradów section, sample K-A 4, slide 3, T 9/2; M - Tripartites vetustus, Szczawno Formation, Konradów section, sample K-A 5, slide 1; N4 - Tripartites vetustus, Wałbrzych Formation, Biały Kamień section, sample P 2, slide 4, O60/3; O-Bellispores nitidus, Szczawno Formation, Konradów section, sample Kon 1, slide 2; P - Cingulizonates bialatus, Szczawno Formation, Konradów section, sample K-A 1, slide 1, K 10/3; R - Cingulizonates bialatus, Wałbrzych Formation, Biały Kamień section, sample P2, slide 3, Q35/4; S - Densosporites spinifer, Szczawno Formation, Konradów section, sample K-A 3, A37/4; T Knoxisporites stephanophorus, Szczawno Formation, Konradów section, sample Kon 36, N23/3; U - Knoxisporites cinctus, Szczawno Formation, Konradów section, sample K-A 6, S 50/1; W - Knoxsporitesi triradiatus, Szczawno Formation, Konradów section, sample K-A 1, I 19/4; X - Reticulatisporites carnosus, Szczawno Formation, Konradów section, sample K-A 3, slide 3, G51/4; Y - Reticulatisporites carnosus, Szczawno Formation, Konradów section, sample K-A 5, slide 1, K 5/1; Z - Orbisporis orbiculus, Szczawno Formation, Konradów section, sample K-A 6, slide 1, N6/2; A' - Orbisporis orbiculus, Szczawno Formation, Konradów section, sample Kon 28, slide 1, S 45; B' Camptozonotriletes cyrenaicus, Szczawno Formation, Konradów section, sample Kon 8, slide 3, Z 52/3; C' - Savitrisporites nux, Wałbrzych Formation, Biały Kamień section, sample P2, slide 1, U57; D' - Stenezotriletes cf. triangulus, Wałbrzych Formation, Biały Kamień section, sample P2, slide 4, G27/2

\footnotetext{
* Supplementary data associated with this article can be found, in the online version, at doi: 10.7306/gq.1581
} 


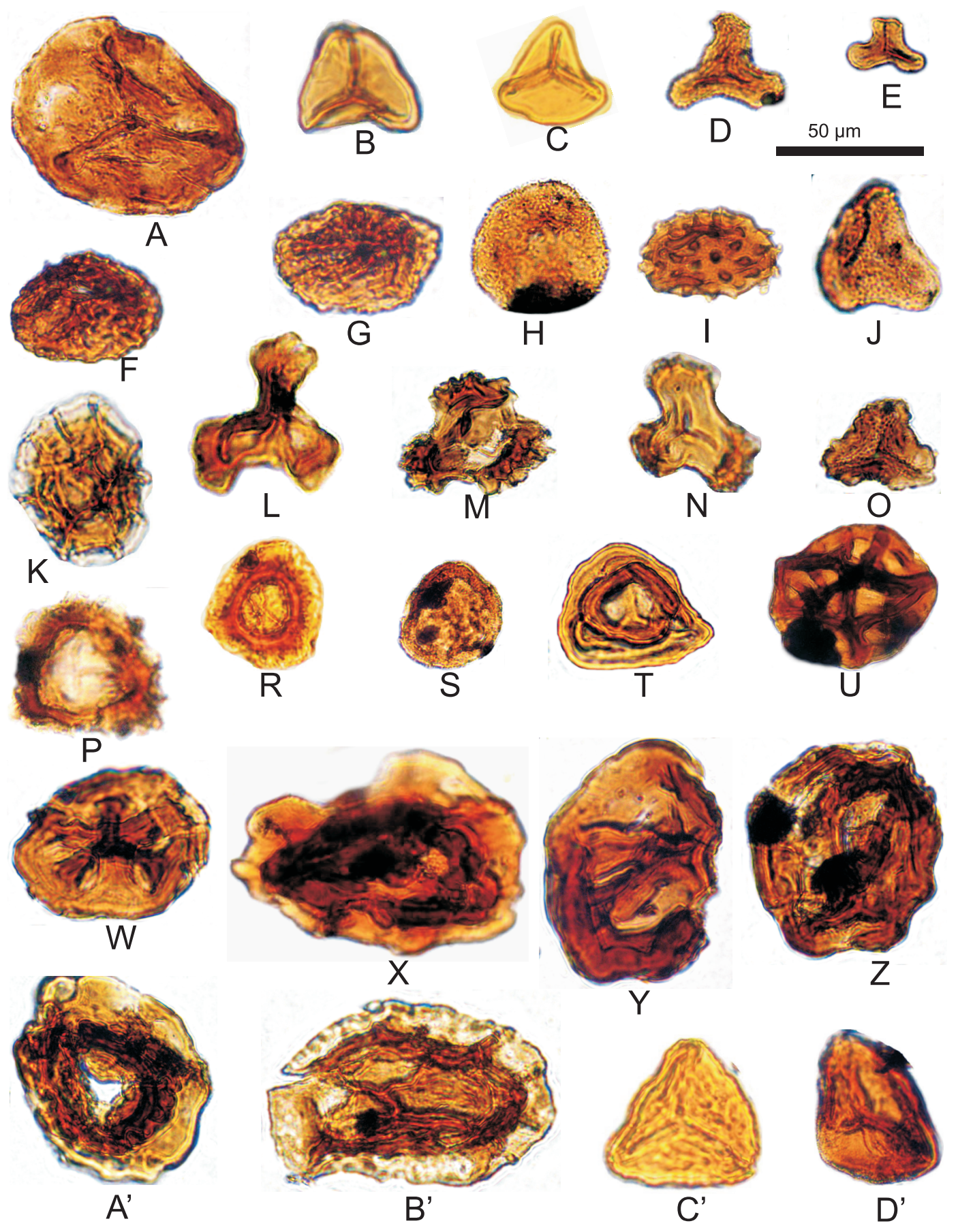

younger than this zone. However, Kraeuselisporites ornatus and Cirratriradites rarus appear just after the disappearance of those two species. Kraeuselisporites ornatus and Cirratriradites rarus together with Stenozonotriletes cf. triangulus suggest that the rocks studied belong to the Lycospora subtriquetra-Krauselisporites ornatus (SO) Zone. The presence of $C$. rarus in both studied samples indicates that these rocks should be included within the upper part of this miospore zone, termed the $L$. subtriquetra-C. rarus (SR) Subzone, where $C$. rarus occurs frequently (Owens et al., 2004; Fig. 8). According to this interpretation, Rotaspora knoxi and Tripartites vetustus would be considered as reworked in this assemblage. Other probably reworked taxa, with imprecisely defined stratigraphic ranges are Dictyotriletes vitilis, Lophozonotriletes variaverrucatus and cf. Monilospora.

\section{DISCUSSION}

The new palynological data from the Szczawno and Wałbrzych formations exposed in the railway section in the WSB has revised the stratigraphic age of these rocks.

The Szczawno Formation in section 1 near Konradów in the northern part of the Intra-Sudetic Basin yielded surprising miospore data, which indicate that the rocks studied are younger than earlier thought. A diverse miospore assemblage with Crassispora kosankei and Verrucosisporites morulatus in the rocks studied undoubtedly indicates a Serpukhovian (Early Namurian) age, belonging to the oldest Namurian V. morulatus $(\mathrm{Vm})$ Miospore Zone. This conclusion contradicts previous dating based on marine macrofauna (Żakowa, 1960a, 1963), 


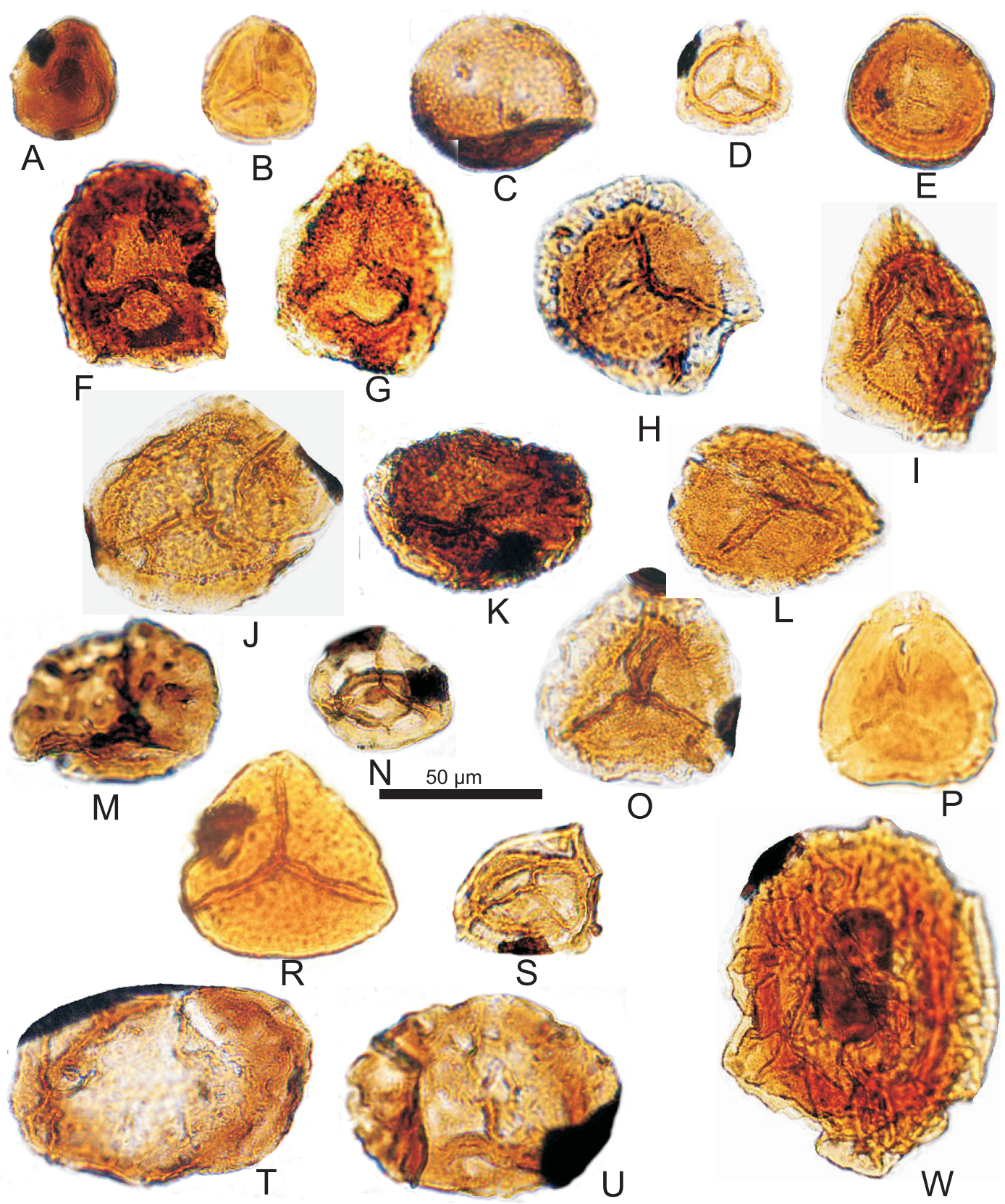

considered until now as the most reliable stratigraphical benchmark in the Carboniferous of the Intra-Sudetic Basin.

The fossil material from the Konradów section described by Żakowa (1960a) is rather poorly preserved, especially the biostratigraphically important goniatites. These are represented only by incomplete external impressions and moulds, without the suture lines. Their identification is difficult and their determination by Żakowa (1960a) on the basis of specimen shape and ornamentation seems to be overinterpreted. Żakowa (1960a) did not take into account that some of the goniatites were found in pebbles and might be reworked (Muszer et al., 2016b). Additionally, the stratigraphic ranges of some Upper Visean taxa were later revised and now extend into the Serpukhovian (genus Nomismoceras - see Kullmann, 2009; Globosochonetes waldschmidti formerly Plicochonetes waldschmidti - see Bojkowski, 1967; Gigantoproductus giganteus, Latiproductus latissimus formerly Gigantoproductus latissimus - see Qiao and Shen, 2015). The stratigraphic range of the bivalve Posidonia becheri now in- cludes the Tournaisian-Namurian (Hoşgör et al., 2012). Finding Calamites (Mesocalamites) cf. renieri, which ranges into the Namurian A, in the Konradów section, is compatibile with the new miospore data. The new age contraints on these rocks ends discussion on the question of the Visean/Namurian boundary located between the Szczawno and Wałbrzych formations, and of the stratigraphic gap associated with this boundary and linked with the Sudetic tectonic phase.

The age interpretation of the Wałbrzych Formation rocks in section 2 at Biały Kamień, given in this paper, indicates that the earlier interpretation of Górecka-Nowak and Majewska (2002, 2003) needs correction. At that time, sampling covered three sections through the Wałbrzych Formation - there are exposures in the forest near Konradów, in Szczawno Zdrój and by the disused railway station in Biały Kamień, now called section 2. In this last section Górecka-Nowak and Majewska (2002, 2003) found Microreticulatisporites concavus, Stenozonotriletes triangulus, Tripartites vetustus, Rotaspora knoxi and 
Fig. 7. Miospores from the Szczawno and Wałbrzych formations

A - Rotaspora knoxi, Szczawno Formation, Konradów section, sample K-A 4, slide 3, W 62/4; B - Rotaspora knoxi, Wałbrzych Formation, Biały Kamień section, sample P1, slide 1', K44; C - Crassispora kosankei, Szczawno Formation, Konradów section, sample K-A 4, slide 1, Q 22/1; D - Lycospora pusilla, Wałbrzych Formation, Biały Kamień section, sample P2, slide 4, H28/2; E - Tholisporites scoticus, Wałbrzych Formation, Biały Kamień section, sample P2, slide 5, H60; F - Cirratriradites saturni, Szczawno Formation, Konradów section, sample K-A 6, slide 3, H 46/4; G - Cirratriradites saturni, Wałbrzych Formation, Biały Kamień section, sample P2, slide 3, U40/4; H - Cirratriradites rarus, Wałbrzych Formation, Biały Kamień section, sample P1, slide 3, U56; I - Cirratriradites rarus, Wałbrzych Formation, Biały Kamień section, sample P1, slide 3', U58/1; J - Cirratriradites rarus, Wałbrzych Formation, Biały Kamień section, sample P1, slide 1', G8/1; K Hymenospora palliolata, Szczawno Formation, Konradów section, sample K-A 2, slide 2, T 45/2; L - Grandispora echinata, Wałbrzych Formation, Biały Kamień section, sample, sample P1, slide 3', B51; M - Grandispora echinata, Szczawno Formation, Konradów section, sample K-A 1, slide 1, T 36/2; N - Retispora staplinii, Szczawno Formation, Konradów section, sample Kon 17, slide 4, Q 41/1; O - Kraeuselisporites ornatus, Wałbrzych Formation, sample P2, slide 6, B17/2; P - Spelaeotriletes arenaceous, Wałbrzych Formation, sample P2, slide 1, W12/2; $\mathbf{R}$ - Spelaeotriletes triangulus, Wałbrzych Formation, sample P2, slide 1, P53/2; S - Vallatisporites ciliaris, Szczawno Formation, Konradów section, sample K-A 1, slide 2, Y14; T - Schulzospora ocellata, Szczawno Formation, Konradów section, sample K-A 3, slide 2, Z 9/2; U Schulzospora ocellata, Szczawno Formation, Konradów section, sample K-A 3, slide 1, X 31; W - Remysporites magnificus, Wałbrzych Formation, Biały Kamień section, sample P1, slide 1, G10

Crassispora maculosa. This, and a similar miospore assemblage these authors determined from the forest exposure near Konradów, were assigned to the $S$. triangulus $-R$. knoxi (TK) Miospore Zone of Clayton et al. (1977). This zone corresponds to the Mooreisporites trigallerus-Rotaspora knoxi (TK) Zone in the revised miospore zonation of Owens et al. (2004). Rocks from Szczawno Zdrój contained miospore assemblage with many specimens of Kraeuselisporites ornatus and were included into the L. subtriquetra-K. ornatus (SO) Miospore Zone (Clayton et al, 1977; Górecka-Nowak and Majewska, 2002, 2003). The lack of $C$. rarus in this assemblage suggests that these rocks should be assigned to the $L$. subtriquetra-Apiculat- isporis variocorneus (SV) Subzone in the miospore zonation revised by Owens et al. (2004).

The Wałbrzych Formation seen in section 2 at Biały Kamień yielded $K$. ornatus and also $C$. rarus. On this basis these rocks are included into the $L$. subtriquetra-C. rarus (SR) Subzone and so were formed later than thought before. These rocks are younger than rocks of the Wałbrzych Formation in the forest exposure near Konradów, but also comparing to rocks from Szczawno Zdrój (Górecka-Nowak and Majewska, 2002, 2003).

The difference, in the miospore assemblage from section 2 at Biały Kamień, obtained during the present and previous palynostratigraphic studies needs comment. In the previous

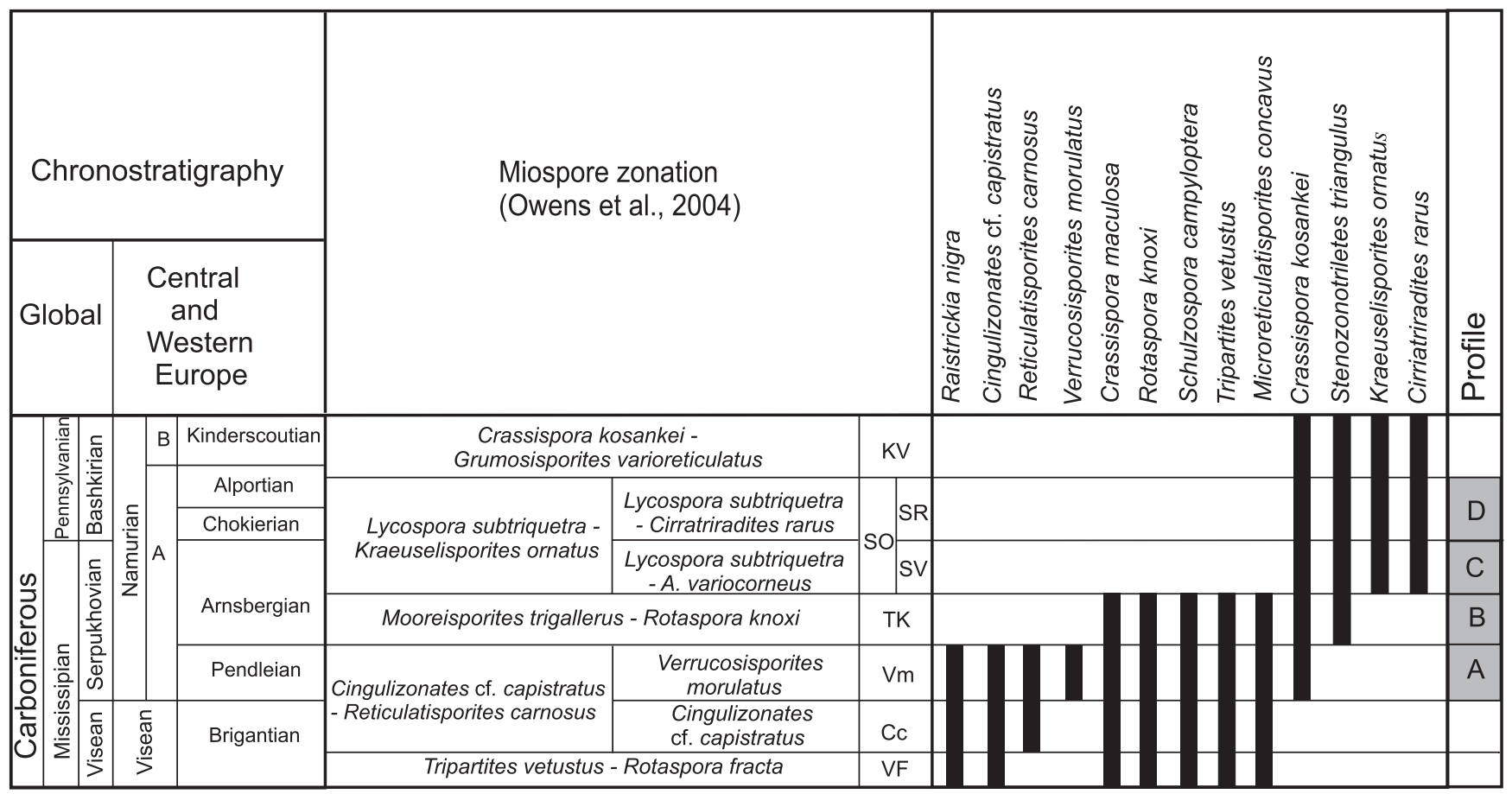

Fig. 8. Chronostratigraphy and miospore zonation of the Carboniferous with stratigraphic ranges of selected miospore taxa (based on Owens et al., 2004) and palynostratigraphy of the Szczawno and Wałbrzych formations in the northern part of the Intra-Sudetic Basin (grey colour shows the part of the profile studied)

A - profile of the Szczawno Formation from section 1 near Konradów (this paper); B - profile of the Wałbrzych Formation from forest exposure near Konradów (Górecka-Nowak and Majewska, 2002, 2003); C - profile of the Wałbrzych Formation from Szczawno Zdrój (Górecka-Nowak and Majewska, 2002, 2003); D - profile of the Wałbrzych Formation from section 2 near Biały Kamień (this paper) 
study only the coal and the coaly shales occurring directly below and above the coal were studied (Górecka-Nowak and Majewska, 2002, 2003). The youngest species determined then was Stenozonotiletes triangulus, while the taxa Kraeuselisporites ornatus and Cirratriradites rarus were not found. These miospore data suggested inclusion to the TK Zone (Górecka-Nowak and Majewska, 2002, 2003). In miospore assemblages of the present study, $C$. rarus was found in both samples studied, with $K$. ornatus present only in mudstones from the upper part of the profile (sample P2; Fig. 4). This taxon in rocks from Szczawno Zdrój is also connected to a mudstone lithology, suggesting that the distribution of this taxon may be palaeoecologically controlled. This may explain why $K$. ornatus was found neither in coal nor in coaly shales associated with phytogenic sedimentation.

The new palynostratigraphic data from the Szczawno and Wałbrzych formations (sections 1 and 2) in the northern part of the Intra-Sudetic Basin complemented the earlier conclusions and show that the rocks studied belong to four Namurian miospore zones or subzones, from Verrucosisporites morulatus $(V m)$ to $L$. subtriquetra-C. rarus (SR) (Owens et al., 2004). The oldest subzone, $V$. morulatus $(\mathrm{Vm})$, was recorded in rocks of the Szczawno Formation in section 1 near Konradów. The next two zones were recorded by Górecka-Nowak and Majewska (2002, 2003). The forest exposure of the Wałbrzych Formation near Konradów was assigned to the $M$. trigallerus- $R$. knoxi (TK) Zone and that at Szczawno Zdrój to the $L$. subtriquetra- $A$. variocorneus (SV) Subzone. The Wałbrzych Formation strata in section 2 near Biały Kamień are assigned to the youngest $L$. subtriquetra-C. rarus (SR) Miospore Zone. This stratigraphic interval corresponds the Lower Namurian, termed the Namurian A in Central Europe and to the Pendleian, Arnsbergian, Chokerian stages as well as to the lower and middle parts of the Alportian in British chronostratigraphy. An important stratigraphic surface, the boundary between the Mississippian and Pennsylvanian, is located in the profile of the Wałbrzych Formation studied. This boundary, which is also the boundary between the $L$. subtriquetra- $A$. variocorneus (SV) and $L$. subtriquetra-C. rarus (SR) zones is not recorded within the Wałbrzych Formation. This means that, in this formation, this boundary must be located somewhere between the monotonous clastic rocks exposed at Szczawno Zdrój and the rocks of section 2 at Biały Kamień

Reworked miospores, mainly only slightly older than the strata studied rocks, usually Visean, though sometimes also Tournaisian, were found in rocks of both formations studied. They were also reported from the Wałbrzych Formation by Górecka-Nowak and Majewska $(2002,2003)$. Their common occurrence in Serpukhovian and Lower Bashkhirian rocks indicates erosion of Visean and Tournaisian rocks took place during sedimentation of the Szczawno and Wałbrzych Formation deposits.

\section{CONCLUSIONS}

Palynostratigraphic studies of the Szczawno Formation from the Konradów section and the Wałbrzych Formation from Biały Kamień near Wałbrzych have provided new data on their age, which revises previous dating. The rocks studied from the Szczawno Formation, once thought to belong to the Upper Visean, are of the Verrucosisporites morulatus $(\mathrm{Vm})$ Miospore Subzone (Owens et al., 2002), representing the lowermost Serpukhovian (Namurian A). Rocks of the Wałbrzych Formation from the Biały Kamien section are included in the $L$. subtriquetra-C. rarus (SR) Miospore Subzone, correlated with the lower Bashkirian (Upper Namurian A). This means that rocks studied from both sections are slightly younger than earlier thought.

These new data complement previous dating of the Wałbrzych Formation (Górecka-Nowak and Majewska, 2002, 2003) and indicate that in the northern part of the Intra-Sudetic Basin, the Szczawno and Wałbrzych formations include four miospore zones and subzones from $V$. morulatus $(\mathrm{Vm})$ to $L$. subtriquetra-C. rarus (Namurian A). The Szczawno Formation includes the oldest subzone corresponding to the lowermost Serpukhovian (Lower Namurian A). The three following zones were recorded in the Wałbrzych Formation which represents the Serpukhovian and Lower Bashkirian (Namurian A).

The boundary between the Szczawno and Wałbrzych formations was once considered as the Lower/Upper Carboniferous boundary (Visean/Namurian boundary), but the new palynostratigraphic dating disproves this inference, as upper part of the Szczawno Formation and the Wałbrzych Formation belong to the Serpukhovian (Namurian A).

The boundary between the Mississippian and Pennsylvanian, correlated to the Serpukhovian/Bashkirian boundary and the boundary between the $L$. subtriquetra-A. variocorneus (SV) and $L$. subtriquetra-C. rarus (SR) zones, is located in the Wałbrzych Formation. This boundary is not recorded, being located between the sections exposed at Szczawno Zdrój and those of section 2 of this study near Biały Kamień.

Aknowledgements. Section 1 of the Szczawno Formation near Konradów was studied in 2012-2015 as part of a grant of the National Science Centre (UMO-2011/01/B/ST10/05112). Some materials and results from the section 2 near Biały Kamien, presented in this paper, were obtained in 2019 as a part of the Master's thesis of A. Jankowska, the second co-author, under the supervision of J. Muszer and A. Górecka-Nowak and financed by research subsidy UWr 2019/501. Ms. A. Strzoda is thanked for the photographs of Calamites from the Konradów section. The authors express their gratitude to the reviewers, P. Filipiak and J. Bek, for their insightful reviews which improved the quality of this paper.

\section{REFERENCES}

Awdankiewicz, M., Kurowski, L., Mastalerz, K., Raczyński, P., 2003. The Intra-Sudetic Basin - a record of sedimentary and volcanic processes in late to post-orogenic tectonic setting. Geolines, 16: 165-183.

Bederke, E., 1929. Die varistische Tektonik der mittleren Sudeten. Forstschritte der Geologie und Paläontologie, 7: 429-524.
Bederke, E., Fricke, K., 1943. Das Niederschlesische Gebiet (Innersudetisches Steinkohlenbecken). Der Deutsche Steinkohlenbergbau, Essen.

Berg, G., 1921. Geologische Karte von Preussen und benachbarten Bundesstaaten. B1. Schreiberhau und Schneegruben-Baude. Preussischen Geologischen Landesanstalt, Berlin. 
Berg, G., 1925. Die Gliederung des Oberkarbons und Rotliegenden im niederschlesisch-böhmischen Becken. Jahrbuch Preussischen Geologischen Landesanstalt, 46: 68-84.

Berg, G., 1938. Erläuterungen zu Geologische Karte Blatt Landeshut (1:25 000). Königlich Preussischen Geologischen Landesanstalt, Berlin.

Bojkowski, K., 1967. Stratigraphy of the Upper Carboniferous oft he Upper Silesia Coal Basin based on fauna. Annales de la Société Géologique de Pologne, 37: 65-99.

Bossowski, A., Ihnatowicz, A., Mastalerz, K., Kurowski, L., Nowak, G.J., 1995. Intra-Sudetic Depression. Prace Państwowego Instytutu Geologicznego, Warszawa, 148: 142-147.

Boureau, E., 1964. Traite de Paleobotanique, T. 3: Sphenophyta, Noeggerathiophyta, Paris.

Buch, L., von, 1802. Geognostische Beobachtungen auf Reisen durch Deutschland und Italien. Hauden and Spener, Berlin.

Clayton, G., Coquel, R., Doubinger, J., Gueinn, J., Loboziak, S., Owens, B., Streel, M., 1977. Carboniferous miospores of Western Europe: illustration and zonation. Report of Commission Internationale de Microflore du Paleozoique. Meded. Rijks Geologische Dienst, 29: 1-71.

Dathe, E., 1891. Über die Discordanz zwischen Culm und Waldenburger Schichten im Waldenburger Becken. Zeitschrift der Deutschen Geologischen Gesellschaft, 43: 277-282.

Dathe, E., 1892a. Geologische Beschreibung der Umgebung von Salzbrunn. Abhandlungen der Preussischen Geologischen Landesanstalt. A., N.F., 13: 131-138.

Dathe, E., 1892b. Über fossile Pflanzenreste mit erhaltener innerer Structur aus dem Culm von Conradsthal. Zeitschrift der Deutschen Geologischen Gesellschaft, 44: 380-381.

Dathe, E., 1901. Die Lagerungsverhältnisse des Oberdevon und Culm am Kalkberge bei Ebersdorf in Schlesien. Jahrbuch der Königlichen Preussischen geologischen Landesanstalt, 21: 214-237.

Dathe, E., 1904. Blatt Neurode und Erläuterungen. Preussischen Geologischen Landesanstalt, A, Berlin.

Dathe, E., Berg, G., 1926. Erläuterungen zu Geologische Karte von Preussen. Blatt Waldenburg, Preussischen Geologischen Landesanstalt, Berlin.

Dathe, E., Finckh, L., 1924. Geologische Karte von Preussen und benachbarten Bundesstaaten. Blatt Charlottenbrunn. Preussischen Geologischen Landesanstalt, 9.

Dathe, E., Petrascheck, W. 1913. Geologische Übersichtskarte des niedeschlesisch-böhmischen Becken. Königlich. Preussischen Geologischen Landesanstalt, A. Berlin

Dziedzic, K., 1960. Quelques problemes géologiques liées avec le promontoire de Culm de Jabłów - Sudétes Moyens. Acta Geologica Polonica, 10: 339-353.

Dziedzic, K., 1968. The problem of Intra-Carboniferous discordances in the north-western part of the Intra-Sudetic Trough (in Polish with English summary). Kwartalnik Geologiczny, 12 (1): 39-50.

Dziedzic, K., 1971. Sedimentation and palaeogeography of the Upper Carboniferous deposits in the Intra-Sudetic Depression (in Polish with English summary). Geologia Sudetica, 5: 7-66.

Dziedzic, K., Teisseyre A.K., 1990. The Hercynian molasse and younger deposits in the Intra-Sudetic Depression, SW Poland. Neues Jahrbuch für Geologie und Paläontologie, Abhandlungen, 179: 285-305.

Gothan, W., 1932. Strukturzeigende Pflanzenreste aus dem Untercarbon (Kulm) von Niederschliesen. Berichte der Deutschen Botanischen Gesellschaft, 50: 400-411.

Gothan, W., Gropp, W., 1933. Paläobotanisch-stratigraphische Untersuchungen im niederschlesischen Karbon. Zeitschrift Berg Hütten und Salinwesen im Preussischen Staate, 81: 88-98.

Górecka, T., 1962. Niektóre wyniki badań sporowych w wałbrzyskiej niecce węglowej (in Polish). Kwartalnik Geologiczny, 6 (4): 785-786.
Górecka, T., 1968. Namurian-Westphalian boundary in the north-western part of the Intra-Sudetic trough (in Polish with English summary). Kwartalnik Geologiczny, 12 (1): 51-64.

Górecka, T., 1969. Stratigraphy of the Biały Kamień Beds in the north-western part of the Intra-Sudetic trough on the ground of palynological research (in Polish with English summary). Biuletyn Instytutu Geologicznego, 230: 167-292.

Górecka, T., 1981. Results of palynostratigraphic tests of the youngest Carboniferous formation in the Lower Silesia region (in Polish with English summary). Prace Naukowe Instytutu Górnictwa Politechniki Wrocławskiej, 40: 1-58.

Górecka-Nowak, A., 1987. Preliminary results of palynostratigraphical studies of rocks from the Grzedy IG-1 borehole (in Polish with English summary). Prace Naukowe Instytutu Górnictwa, 49, Studia i Materiały, 17: 22-35.

Górecka-Nowak, A., 1988. Palynostratigraphy of Upper Carboniferous deposits from the Grzędy IG-1 borehole (northern part of the Intra-Sudetic Basin) (in Polish with English summary). Geologia Sudetica, 23: 103-119.

Górecka-Nowak, A., 1995. Palynostratigraphy of the Westphalian deposits in the north-western part of the Intrasudetic basin (in Polish with English summary). Acta Universitatis Wratislaviensis, 1583. Prace Geologiczno-Mineralogiczne, 40: 1-156.

Górecka-Nowak, A., Majewska, M., 2002. Remarks on palynostratigraphy of the Namurian Wałbrzych Formation in the northern part of the Intra-Sudetic Basin (SW Poland). Geological Quarterly, 46 (2): 101-115.

Górecka-Nowak, A., Majewska, M., 2003. The palynostratigraphy and palynofacies of the Namurian Wałbrzych Formation in the northern part of the Intra-Sudetic Basin (SW Poland). In: Proceedings of the XVth International Congress on Carboniferous and Permian Stratigraphy: 333-342.

Grocholski, A., 1960. Notes on geological structure of western region of Wałbrzych (in Polish with English summary). Kwartalnik Geologiczny, 4 (3): 631-646.

Grocholski, A., 1963. Results of geological investigations in the Lower Silesian Coal Basin (in Polish with English summary). Przegląd Geologiczny, 11: 323-401.

Grocholski, A., 1974. Stratigraphical problems of the Silesian in the Lower Silesian Coal Basin (in Polish with English summary). Kwartalnik Geologiczny, 18 (1): 63-79.

Grocholski, A., Augustyniak, K., 1971. Geological atlas of the Lower Silesian Coal Basin 1:50 000. Part 1 (in Polish). Instytut Geologiczny, Warszawa.

Hoşgör, I., Okan, Y., Göncüoğlu, M.C., 2012. Posidonia becheri Bronn, 1828 from the Tournaisian of SE Turkey: a palaeobiogeographic enigma. Comptes Rendus Palevol, 11: 13-20.

Jerzykiewicz T., 1965. New Culm fauna from Konradów near Wałbrzych (in Polish with English summary). Acta Geologica Polonica, 15: 219-236.

Jerzykiewicz, J., 1987. Late Carboniferous (Stephanian) and Early Permian (Autunian) palynological assemblages from the Intra-Sudetic Basin, SW Poland. Palynology, 11: 117-131.

Kotasowa, A., Migier, T., 1995. Macroflora. Prace Państwowego Instytutu Geologicznego, 148: 56-65.

Kotasowa, A., Migier, T., 2001. Klasa Lycopsida (in Polish). In: Budowa Geologiczna Polski. T. III. Atlas skamieniałości przewodnich i charakterystycznych. Cz. 1c, z. 2. Młodszy paleozoik. Karbon. Flora. Makroflora (ed. M. Pajchlowa): 772-784. Państwowy Instytut Geologiczny, Warszawa.

Krawczyńska-Grocholska, H., 1966. Le Namurien du Bassin de Nowa Ruda a' la lumiére des études palynologiques. Geologia Sudetica, 2: 323-401.

Kullmann J., 2009. Nomismoceraidea. In: Treatise on Invertebrate Paleontology (eds. M. Furnish, B. F. Glenister, J. Kullmann and Z. Zuren): 35-39. Part I. Mollusca 4. The University of Kansas Palaeontological Institute. Lawrence, Kansas.

Kühne, F., 1930. Die Gastropoden des deutschen Untercarbons. Abhandlungen Preussischen Geologischen Landesanstalt, 122: 93-141. 
Mastalerz, K., 1987. Sedimentation in the Intra-Sudetic Basin at the Lower and Upper Carboniferous transition. In: Guidebook of the 58-th Meeting of Polish Geological Society at Wałbrzych (eds. Z. Baranowski, A. Grocholski, J. Malinowski, J. Oberc and S. Porębski): 134-145. Zakład Graficzny, Kraków.

Mastalerz, K., 1995. Deposits of high - density turbidity currents on fan - delta slopes: an example from the Upper Visean Szczawno Formation. Intra-Sudetic Basin, Poland. Sedimentary Geology, 98: 121-146.

Mastalerz, K., Porębski S., 1987. Fan-delta complexes in a Visean low-energy marine embayment, Intrasudetic Basin (SW Poland). In: International Symposium "Fan Deltas - Sedimentology and Tectonic Settings" (ed. W. Nemec): 139-140. Abstracts. University of Bergen, Bergen.

Mastalerz, K., Prouza, V., 1995. Development of the Intra-Sudetic Basin during Carboniferous and Permian. In: Sedimentary record of the Variscan orogeny and climate - Intra-Sudetic Basin, Poland and Czech Republic (eds. K. Mastalerz, V. Prouza, L. Kurowski, A. Bossowski, A. Ihnatowicz and G. Nowak): 5-15. Guide to excursion B1. XIIIth International Congress on Carboniferous-Permian, August 28-September 2, Kraków, Poland. Państwowy Instytut Geologiczny, Warszawa.

Mastalerz, M., 1992. Petrography and depositional conditions of the coal seams of the Wałbrzych Formation, Intra-Sudetic Basin, SW Poland. Geologia Sudetica, 26: 47-82.

Muszer, J., Górecka-Nowak, A., Kryza, R., August, C., 2016a. New data on biostratigraphy and chronostratigraphy of the Carboniferous sediments in Sudetes (in Polish). In: XXIII Konferencja Naukowa Sekcji Paleontologicznej Polskiego Towarzystwa Geologicznego (eds. K. Pawłowska and D. Pawłowski): 73-740. 21-23 września 2016 Poznań, Abstrakty.

Muszer, J., Królewiecka, K., Strzoda, A., 2016b. Redeposition of the Upper Visean in the Namurian sediments of Sudetes - examples from Konradów and Jugów (in Polish). In: XXIII Konferencja Naukowa Sekcji Paleontologicznej Polskiego Towarzystwa Geologicznego, Poznań 21-23 września 2016. Abstrakty (eds. K. Pawłowska and D. Pawłowski): 75-76.

Nekhoroshev, B., 1932. Die Bryozoen des deutschen Unterkarbons. Abhandlungen Preussischen Geologischen Landesansalt, 141: 4-74.

Nemec, W., 1984. Wałbrzych Beds (Lower Namurian, Wałbrzych coal measures): analysis of alluvial sedimentation in a coal basin (in Polish with English summary). Geologia Sudetica, 19: 7-67.

Nemec, W., Porębski, S.J., Teisseyre, A.K., 1982. Explanatory notes to the lithotectonic molasses profile of the Intra-Sudetic Basin, Polish Part (Sudety Mts., Carboniferous-Permian) (Comment to Annex 23). Veröffentlichungen des Zentralinstituts für Physik der Erde. Akademie der Wissenschaften der DDR, Potsdam, 66: 267-278

Nowak, G.J., 2000. Thermal maturity of coals from the Lower Silesian Coal Basin on the background of their petrography and Genesis (in Polish with English summary). Biuletyn Państwowego Instytutu Geologicznego, 391: 89-146.

Oberc, J., 1957. Region Gór Bardzkich. Przewodnik geologiczny (in Polish). Wyd. Geol., Warszawa.

Osmólska, H., 1968. Contributions to the lower Carboniferous Cyrtosymbolinae (Trilobita). Acta Palaeontologica Polonica, 13: 119-147.

Owens, B., McLean, D., Bodman, D., 2004. A revised palynozonation of British Namurian deposits and comparsion with eastern Europe. Micropaleontology, 50: 89-100.

Qiao, L., Shen, S.-Z., 2015. A global review of the Late Mississippian (Carboniferous) Gigantoproductus (Brachiopoda) faunas and their paleogeographical, paleoecological, and paleoclimatic implications. Palaeogeography, Palaeoclimatology, Palaeoecology, 420: 128-137.

Paeckelmann, W., 1930. Die Brachiopoden, 1. Teil. In: Die Fauna des deutschen Unterkarbons. Die Brachiopoden, Teil 1.
Abhandlungen der Preussischen Geologischen Landesanstalt, 122: 143-326.

Paeckelmann, W., 1931. Die Fauna des deutschen Unterkarbons. Die Brachiopoden, Teil 2. Abhandlungen der Preussischen Geologischen Landesanstalt, 136: 1-440.

Radwański, S., 1952. Paleogeografia i sedymentacja kulmu w północnej części niecki śródsudeckiej (in Polish). Biuletyn Państwowego Instytutu Geologicznego, 79: 123-146.

Raumer K., von, 1819. Das Gebirge Niederschlesiens, der Grafchaft Glatz und eines Theile von Böhmne und der Ober-Laustiz. Reminer, Berlin.

Schmidt, H., 1930. Vergleich unserer Karbonschichtenfolge mit der Russlands. Zeitschrift der Deutschen Geologischen Gesellschaft, B, 81: 146-147.

Sawicki, L., 1966. Geological Map of Lower Silesia 1:200 000 without Quaternary deposits. Wyd. Geol., Warszawa.

Sawicki, L., 1995. Geological Map of Lower Silesia with adjacent Czech and German territories (without Quaternary deposits) 1:100 000. Państwowy Instytut Geologiczny, Warszawa.

Teisseyre, A.K., 1968. The Lower Carboniferous of the IntraSudetic Basin: sedimentary petrology and basin analysis. Geologia Sudetica, 4: 221-298.

Teisseyre, A.K., 1975. Sedimentology and paleogeography of the kulm alluvial fans in the western Intra-Sudetic Basin (Central Sudetes, SW Poland). Geologia Sudetica, 9: 5-125.

Teisseyre, H., 1952. Geological structure of the northern region of Wałbrzych (Lower Silesia) (in Polish with English summary). Biuletyn Instytutu Geologicznego, 62: 1-58.

Teisseyre, H., 1958. Sedimentation, paleogeography and tectonics of the Lower Carboniferous in the Middle Sudeten (in Polish with English summary). Kwartalnik Geologiczny, 2 (3): 576-586.

Teisseyre, H., 1961. On the problem of unconformity between Lower and Upper Carboniferous in the Middle Sudetes. Bulletin de l'Academie Polonaise des Sciences, Série des Sciences Géologiques et Géographiques, 9: 53-61.

Turnau, E., Żelaźniewicz, A., Franke, W., 2002. Middle to early late Viséan on set of late orogenic sedimentation in the Intra-Sudetic Basin, West Sudetes: miospore evidence and tectonic implication. Geologia Sudetica, 34: 9-15.

Uglik, M., Nowak, G.J., 2015. Petrological recognition of bituminous inertinite enriched coals of the Lower Silesian Coal Basin (Central Sudetes, SW Poland). International Journal of Coal Geology, 139: 49-62.

Woszczyńska, S,. 1967. Foraminifers of the Lower Carboniferous from Wałbrzych and from certain areas of Sowie Mts. (in Polish with English summary). Kwartalnik Geologiczny, 11 (1): 76-83.

Zimmermann, F., 1956. Paleobotanical notes from the Lower Silesian Carboniferous (in Polish with English summary). Biuletyn Państwowego Instytutu Geologicznego. 98: 125-180.

Żak, C., 1958. Structure and the development of the western limb of the Intrasudetic Basin (in Polish with English summary). Biuletyn Instytutu Geologicznego, 129: 5-109.

Żakowa, H., 1958. Upper Visean of the Lower Carboniferous Intrasudetic Basin (in Polish with English summary). Kwartalnik Geologiczny, 2 (3): 609-625.

Żakowa, H., 1960a. The Upper Visean from Konradów near Wałbrzych (Lower Silesia) (in Polish with English summary). Kwartalnik Geologiczny, 4 (2): 331-345.

Żakowa, H., 1960b. New locality of Upper Visean fauna from Wałbrzych Miasto (in Polish with English summary). Kwartalnik Geologiczny, 4 (3): 619-642.

Żakowa, H., 1963. Stratigraphy and facial extents of the Lower Carboniferous in the Sudetes (in Polish with English summary). Kwartalnik Geologiczny, 7 (1): 73-94.

Żelaźniewicz, A., Aleksandrowski, P., Buła, Z., Karnkowski, P.H., Konon, A., Oszczypko, N., Ślączka, A., Żaba, J., Żytko, K., 2011. Regionalizacjatektoniczna Polski (in Polish). Komitet Nauk Geologicznych PAN, Wrocław. 